\title{
Rural Women Farmers and Food Productivity in Nigeria: An Example from Ekiti Kwara, Nigeria
}

\author{
Olawepo. R. A. ${ }^{1} \&$ Bola Fatulu ${ }^{1}$ \\ ${ }^{1}$ Department of Geography and Environmental Management, University of Ilorin, Nigeria \\ Correspondence: Olawepo. R. A., Department of Geography and Environmental Management, University of \\ Ilorin, Nigeria. E-mail: ralfabbey@yahoo.com
}

$\begin{array}{lr}\text { Received: February 6, } 2012 & \text { Accepted: April 27, } 2012 \quad \text { Published: August 1, } 2012 \\ \text { doi:10.5539/ass.v8n10p108 } & \text { URL: http://dx.doi.org/10.5539/ass.v8n10p108 }\end{array}$

\begin{abstract}
This paper describes the earning activities of Rural Women Farmers in Ekiti Kwara to identify processes of food production and Agriculture within a farming season.200 farmers were examined through the use of questionnaire administration. Results were processed through the use of simple tabulations and inferential statistics. Findings revealed that that $75.5 \%$ of the respondents have access to land for farming while the remaining $24.5 \%$ not to have a land of their own ,but they are those that depend on either family lands or go on leasing from other land owners. Apart from their mothering roles, women here are contributing heavily to nutritional development, farm employment and food security. About $54.5 \%$ of the women farmers in the study area provides food for their household; topmost in their farm productions are in the area of vegetables, fruits livestock and fishery. However, income earnings from farm is generally low due to the subsistent nature of their production . The result of the stepwise multiple regression showed that about $75.69 \%$ differences in the variation of women participation is explained by three variables of supplementing income, debt servicing measure and food security respectively and appropriate recommendations are presented accordingly.
\end{abstract}

Keywords: participatory, production, household, development, income, agriculture, poverty

\section{Introduction}

For quite a long time, agriculture has continued to play a dominant role in the Nigerian economy. Prior to the oil boom, the Agricultural sector accounted for more than half of the Gross Domestic Product (GDP), and employed about 80 percent of the adult working population (Olawoye, 1989) and Adeyokunnu, 1981). However, faster developments in other sectors of the economy particularly in the petroleum sub-sectors have thwarted the percentage contribution of Agriculture. Depending on socio-cultural factors of an area, Women's labour input on the farm could be as high as between 60-80 percent of total agricultural labour input for the region (Pala, 1976; Lamming, 1983). Amali (1989) goes further to elaborate on women's specialty areas where their labour input is highest. These include food production, food processing and the marketing of agricultural commodities (both raw and processed) and they are in a way ensuring food security and nutritional development.

Women are the major food crop producers and distributors today in most developing countries because men were encouraged by the Colonial policy of export oriented agricultural production to concentrate on export crops for its cash gains (Banwo, 1986). Following the United Nation's inauguration in 1975 of the United Nation Decade for Women, significant revelations have come to light through studies, which show that women have long been unrecognized corner stones of many rural economics, especially those of the developing nation (Egunjobi 1995).Agriculture, which is the act of cultivation of land and rearing of animals, is not usually considered as a major occupation for both male and female in many countries. Even in Nigeria, the belief in many tribes is that agriculture is not for both sexes. It is believed that women are subordinate and that their role is centered on domestic affairs as a saying goes: "a woman's life ends in the kitchen". This is peculiar to the life of women in most rural areas. It is observed that agricultural activities reflect sexual division of labour in Africa. For example, cash tree crops and energy demanding farm works such as cultivation and plugging are dominantly performed by men or tractors while women on the other hand were usually engaged in other farm works such as weeding, harvesting, storage and marketing, in addition to household or domestic activities. In Nigeria, women are the primary labour force of small farms (FAO, 1995). 
Women farmers, by and large, operate with the most rudimentary tools while labour saving devices benefit mostly men. There are instances where men use such devices or mechanized equipments to even displace or marginalize women from traditional female type jobs such as in cassava processing i.e. gari, rice harvesting and processing etc.

The basic questions still remain:

i. In what ways are the women contributing to food production in the study areas?

ii. What is the level of the food production ability of women?

iii. What are the major influences that attract women into food/farming production in the study area?

These and other questions will be answered in the process of this research work.

The main aim of this study is to examine the roles played by women in food production and to assess the extent of their contribution to food production and nutritional development. It is also to assess the spatial distribution of women's food production abilities in the study as well as to assess the factors that attract women to food production especially in the area of farming.

\section{Women and Participatory Development}

It is impossible to disentangle the concept of participation from some understanding of community development. Indeed in the past decades it has to be branded by some as a key element in community development and that if only it could be meaningfully inserted into the development process, success would be ensured. Thus, women participation is seen as the means of widening and redistributing of opportunities to take part in societal decision making in contributing to development and in benefiting from its fruits. In the past, women contribution to economic development especially in developing Countries was not recognized and seriously underestimated. Emphasis has been placed mainly on reproductive roles than the productive role this is because in our society, male oriented ideology is always prevailing. According to Egunjobi (1987) more than $50 \%$ of the total population in Nigeria are women and are uneducated. Mostly, these women are engaged in agricultural production as their sole occupation and source of income for living, and there are some who combine agricultural jobs with other jobs like; sewing, hair plating, and petty trading among others.A number of studies carried out in many Nigerian cultures provide us with useful guidelines as to the functional importance of women in the socio-economic life of the families. In the study of Abeokuta North Local Government Area of Ogun State edited by Olufade (1997), It was shown that certain agricultural operations such as harvesting, storage, fertilizing and marketing were undertaken wholly by women while men concentrated their attention on operation like land clearing weeding and mulching. A greater number of women devote their time on food crop production; hence they tend towards solving problem of food crisis.

Research also shows that women participate in direct productive farm works at varying degrees; it also shows that men and women have separate but complementary responsibilities on farm works. Women are found to perform crucial roles in all aspects of crops production but importantly in harvesting and post operations on food crops. On the other hand men are said to feature more in preparation and weeding than women. Women participate in planting, collecting and harvesting crops in addition to transporting them home. They also help men to clear grass, weeds and scare birds from grains if the husband has to be away for an extended period. Women cultivate their own small millet fields to be used for additional food (Meek 1994).

\section{The Study Area}

Ekiti Local Government Area (L.G.A.) which is the study area was before the $7^{\text {th }}$ October 1991 part of Irepodun Local Government Area of Kwara State, Nigeria. With the determination of the last Millitary Administration to bring government services nearer to the people, the Ekiti Local Government Area was carved out of Irepodun Lcal Government Area. Thus Ekiti LGA is one of the sixteen Local Government Areas in Kwara State with its headquarters at Araromi Opin. The Local Government has an area of about 747 square kilometers, it extends from latitude $70^{0} 45^{1}$ North in it Northern part to latitude $7^{\circ} 45^{1}$ North in its Southern tip. It also lies between longitude $5^{\circ}$ $30^{1}$ South and $5^{\circ}$ East in the Eastern reach (Rotimi 1992).It shares common boundaries with Ifelodun Local Government and Edu Local Government to the North and Kogi State to the East, Oke-Ero and Irepodun Local Government to the West. Also to the South, it has a common boundary with Ondo State.The population of Ekiti was 95,989, as put forward by the Fed. Ministry of Finance and Economic Development in 1991.

The study area also has some large settlements, which serves as market centers. The marketing organization for cash crop produce is very elaborate especially in those areas bordering the forest region of the South. There are some commercial banks in the study area such as National Bank, United Bank for Africa and Community Bank 
respectively. The basic organization unit for most of her economic activities especially farming is the family and all the communities practice farming, fishing, animal husbandry and petty trading.

\section{Research Methodology}

Data for this work depend largely on primary sources by the use of structured questionnaires, interviews and personal observation. Questionnaires are constructed to allow for the collection of relevant information on the specified variable to be investigated as well as on any other additional aspects that would be relevant for the analysis, other sources of data are derived from secondary publications especially those relating to information on women and farming techniques.

A multi-stage sampling technique was adopted to select respondents in the study area using five districts for sample frame due to the population of the area. The sampling frame is the woman involved in food production and other agricultural related functions. First, the procedure involves random selection of one village in each of the five districts. They include Obbo-ile Ora districts (Obbo ile) Oke-Opin district (Oke Opin) Etan district (Etan) opin districts (Epe-Opin) Osi district (Osi).The total population of Ekti Local Government area is 38,028, 19630 are female while 18,398 constitute male and the number of house is 7,774. Ministry of finance and Economic development 1991. For each village 40 questionnaires were distributed. Judgmental approach was used in selecting the number of the questionnaire, because every woman farmer in the five districts cannot be sampled because precise information and record on women farmers are not kept.

Various appropriate forms of descriptive statistics such as frequency distribution, table percentages were used to explain the various variables. In measuring the factors of participating development, a regression model was used after considering the levels of participation, and stepwise multiple regression analysis was adopted to identify the most important variables explaining the reasons for women participation into agriculture/food production in the study area. The model thus is:

$$
\mathrm{Y}=\mathrm{a}+\mathrm{bx} 1+\mathrm{bx} 2 \ldots \ldots \ldots \ldots . . . .6 x n+e
$$

Where $\mathrm{Y}=\%$ of women participation in food production by district. $\mathrm{a}=$ intercept, $\mathrm{e}=$ error terms, $\mathrm{bx} 1-\mathrm{bxn}=$ regression coefficients and $\mathrm{xi}-\mathrm{xn}=$ motives of participation. Others include:

$\mathrm{x} 1$ = income supplement

$\mathrm{x} 2=$ debt servicing measure

$\mathrm{x} 3=$ accessibility to land ownership of land

$\mathrm{x} 4=$ food security

$\mathrm{x} 5=$ skills and experience

$\mathrm{x} 6=$ personal interest

$\mathrm{x} 7=$ cultural factor

$\mathrm{x} 8=$ level of education

$\mathrm{x} 9=$ numbers of male in the family

$\mathrm{x} 10=$ un employment

$\mathrm{x} 11=$ accessibility to capital

These variables were selected on the basis of past studies and the peculiarity of women farmers in the study area.

\section{Analyses \& Discussion of Results}

\subsection{Introduction}

In order to explain the roles of women in food productivity in the study area, there is need to examine some background information about the women farmers. Efforts are therefore made here to discuss the general characteristics of our respondents as well as their responses to salient issues affecting productivity within a farming season.

\subsection{General Characteristics of Respondents}

For the purpose of analysis Table 1 shows the age distribution of the respondents in the study area. In all 200, (7.5\% ) of them fall within the range of less than 25 years,. while $45 \%$ of the respondents fall within the range of 36-60 years. People in this category participate most in agricultural production in the area and this is followed by people within the age range of $31-35$ years with $25.5 \%$. Out of the 200 respondents 30 of them happen to be within the age above 60 years and this constitutes $15 \%$ of the total labour force. However, the effect of this may be 
as a result of rural - urban migration of the young and able body women in search for good Education, social amenities, good jobs etc. who have moved to the urban centres. The implication of this is that when elderly people are practicing farming or agricultural production mostly, farm outputs will definitely be very low.

Table 1. Age structure of women farmers

\begin{tabular}{llll}
\hline Age Range & Frequency & Percentages & Cumulative $\%$ \\
\hline$<25$ & 15 & 7.5 & 7.5 \\
$25-30$ & 14 & 7.0 & 14.5 \\
$31-35$ & 51 & 25.5 & 40 \\
$36-60$ & 90 & 45 & 85 \\
Above 60 & 30 & 15 & 100 \\
\hline
\end{tabular}

Source: Authors' Research

The particular issues which affect women relate to the fact that their rights to farm land are determined by their marital status. This study reveals that $25(12.5 \%)$ of the respondents are single and from the observation made, it was noticed that transporting of farm output by head is majorly done by single females in this part of the country having in mind that they are stronger than the married. The survey also reflects that 63\% (126) of the married women are involved in agricultural production most especially in planting, harvesting and storage of the farm output. The widows and the divorced were not left out in the production of food for human consumption. In terms of education however, out of the 200 women sampled only $10 \%$ has post secondary education, this set of people are majorly Teachers in either primary or secondary schools of these villages. They engage in farming activities so as to help their growing families and each time the monthly salary is delayed they rely on farm output for survival. Similarly about $29.5 \%$ of the respondents have secondary education, while the remaining $32.5 \%$ have primary education and $25 \%$ have non-formal education. None of the respondents had passed through Quranic education. From the observation made, it was observed that most of the women farmers are not educated formally and even those with primary education cannot express themselves well in English language. Illiteracy has been affecting agricultural production in this area because people who are not educated are used to the primitive way of planting crops and rearing of animals, mostly the use of hoes, cutlasses, axe and this will always affect the crop yield. However, illiteracy is a common feature in the rural area and this factor has made majority of them to go into farming as their major source of livelihood.

\subsection{Subsidiary Occupations of Women}

Women in Ekiti Local Government Area of Kwara State engaged/involved in varieties of occupations. This ranges from petty trading, sewing/tailoring, hair plaiting, fishing and food processing. Table 2 shows the distribution pattern of women labour force in the study area. About $35.4 \%$ are trading and this is the major or most popular job after farming that women get themselves involved in and this is because most of them are full time housewife due to their non formal education. Nevertheless, $21 \%$ of the respondent involved in sewing/tailoring and $18 \%$ in hair plating. Other occupations apart from the ones listed i.e. gari processing, Teaching, operating food canteen take $35.4 \%$ of the respondent while fishing has the least occupation with $9.6 \%$ of the respondents and others take $16 \%$.

Women involvement in other occupations might be as a result of the change in the economic situation in the country generally, exposition to larger marketing environment or the influence of Better life for Rural Women's Programme in Kwara State. This form of shift in the role of women in labour force had been reported by Oyedipe (1986).

Table 2. Women occupation apart from farming

\begin{tabular}{lllll}
\hline Occupation & Frequency & $\begin{array}{l}\text { Cumulative } \\
\text { Frquency }\end{array}$ & Percentage & $\begin{array}{l}\text { Cumulative } \\
\text { Percentage }\end{array}$ \\
\hline Petty Trading & 74 & 74 & 35.4 & 35.4 \\
$\begin{array}{l}\text { Sewing/Dress } \\
\text { making }\end{array}$ & 44 & 118 & 21 & 56.4 \\
Hair plaiting & 38 & 156 & 18 & 74.4 \\
Civil Service & 19 & 175 & 9.6 & 84 \\
Others & 34 & 200 & 16 & 100 \\
\hline
\end{tabular}

Source: Authors' Field work 


\subsection{Women Farmers and Food Security}

The issue of food security in the rural areas of Nigeria deals with availability, accessibility as well as the quality of food being provided. In order to have a wider view of food productivity in the area, there is need to examine, farming, land ownership as well as values of food produced from the women's farms.

\subsection{Farm Ownership and Accessibility to Land}

A married woman may gain access to land, if she has her husband's authorization but is likely to lose this in the event of breakdown in relations, divorced or widowhood. Her right may also change if her husband remarries with a polygamous arrangement. In the discussion below, these issues are examined in relation to a woman's right of access to land. This study reveals that $95.5 \%(193)$ of the respondents agreed to the fact that the tradition of the village or the community they belong to allowed women to own a piece of land while the remaining $3.5 \%$ (7) of the respondents do not agree to it. Hence, there are no serious cultural barriers to women having access to farm land in the five districts. This study further reveals that $75.5 \%(151)$ of the respondents have access to land for farming while the remaining $24.5 \%$ (49) claim not to have a land of their own. The result acquired from these five districts is far above expectation in the sense that in the past, women have been denied the opportunity of owing land for farming or other activities. However, Table 3 revealed that 82.5(165) of the women farmer in Oke-Opin, Obbo-Ile, Etan, Osi Opin and Epe Opin acquired their farm land majorly through their husband. The findings conform to those of the World Bank (1994) that the purchase of farmland in Nigeria is comparatively rare for both men and women. The World Bank (1994) also found that land was allocated to women from their husbands. This corroborates the claim that women farmers' access to land is often mediated through marriage.

Table 3. Land ownership among women farmers

\begin{tabular}{lllll}
\hline Source of land & Frequency & $\begin{array}{l}\text { Cumulative } \\
\text { Frequency }\end{array}$ & $\%$ & Cumulative \% \\
\hline Husbands & 165 & 165 & 82.5 & 82.5 \\
Family & 30 & 195 & 15 & 97.5 \\
Community & 5 & 100 & 2.5 & 100 \\
\hline
\end{tabular}

Source: Authors' Field work

It is clearly known that most married women gain access to farmland through their husband but a woman may have to explore alternative means of access to land for cultivation when she cannot obtain land through her husband. Access to land can also be obtain though a woman male relatives such as father, uncle, brothers or son etc. if they live close by and have sufficient land available.

It was observed in this study that a total of $66 \%$ of women held less than 1 hectare of farmland i.e $30.8 \%$ held less than 0.5 hectare, $35.2 \%$ held between $0.5-1$ hectare while $34 . \%$ held above 1 hectare of farm land. This shows that majority of women farmers in the study area cultivate small farms of less than 1 hectare. This means that majority are still operating on a subsistence level either to supplement incomes or to support their husbands especially where they also engage in farming.

\subsection{Provision of Food by Rural Women}

The important role played by rural women in providing for their household can not be over stressed. Apart from the care of young children, they also contribute foodstuffs. Table 4 shows that 99.5\%(199) of the women farmers in the study area provides food for their household while $0.5 \%(1)$ of the 200 respondents is in contrary. This means that almost every women farmer in the five districts provides food for their household.

Also, most of the crops grown in this area among the women farmers include Yam, Cassava, Maize, Guinea Corn, Beans, Rice and Sweet Potatoes. Others include ground nut, crops like tomatoes, pepper, okro, vegetables to mention a few. Table 4 reveal that $31.1 \%$ (73) of the women farmer grow yam. Following closely is the production of Cassava that constitutes 21.6\%(52) of the crops grown. This is often processed into garri, cassava flour, fufu and the leaf is used to prepare soup especially among the itinerant farmers from Benue State. Maize production is about $17.8 \%$ (43) of the crop grown, while Guinea corn, and beans are produced by about $16.2 \%$ and $2.1 \%$ of the women farmers respectively. These are mostly planted in Epe, Osi and Etan respectively. Other crops include Rice $0.8 \%$ and sweet potatoes $6.2 \%$ also found mainly in Epe. Other crops grown constitute $4.1 \%$ of the total food crops. This include vegetables like tomatoes,spinach,local tete herbs, Ugwu, Lettuce and fruits. Apart from their mothering roles, Rural women perform well in general crop production and in nutritional development, there by ensuring 
food availability and security in the rural environment. It is noticed that more than $80 \%$ of these farm produced are sold in their local markets at Osi, Epe, Iloffa and Ishare Opin to mention a few.

Table 4. Food productivity by women farmers

\begin{tabular}{lllll}
\hline Food Crops & Frequency & $\begin{array}{l}\text { Cumulative } \\
\text { Frequency }\end{array}$ & $\%$ & Cumulative \% \\
\hline Yam & 75 & 75 & 31.1 & 31.1 \\
Cassava & 52 & 127 & 21.6 & 52.2 \\
Maize & 43 & 170 & 17.8 & 70 \\
Ginea corn & 39 & 209 & 16.2 & 86.2 \\
Beans & 5 & 214 & 2.1 & 88.3 \\
Rice & 2 & 216 & 0.8 & 89.1 \\
Sweet Potatoes & 15 & 23.1 & 6.2 & 95.3 \\
Fruits /Vegetables & 10 & 241 & 4.1 & 100 \\
\hline
\end{tabular}

Source: Authors' Field work

The extent of women agricultural activities seems to be limited more by their overall heavy workload. Therefore, Table 5 shows different sources of farm labour among the respondent. $146(33.3 \%)$ of the women farmer in this district work on their farm with support from no one. They cultivate the land, cultivate, weed, fertilize etc by themselves. 10.5\% (46) received assistance from their husband, 18\% (79) got assistance through their children while $37 \%$ (162) make use of hired labour on their farm while other such as sisters, brothers, daughters in-law make up the $1.2 \%(5)$ of the respondent and the least among the options.

Those that hire labour constitute the highest figure because they are still within the age of 19years - 35years (active years) most of them operates on large farmland and they convey most of their farm output to another town to sell. Those that have their husband and children assistance used their farm produce majorly on consumption.

In terms of women's works on the farm, it was observed that women are involved in the less strenuous works, while the more strenuous works like weeding, making of heaps and tree felling are done through hired labourers, who are usually men from their villages or migrants farmers who specialize in farm labours. Some still involve in hoeing, but at a very small level.

Table 5. Sources of farm labour

\begin{tabular}{|c|c|c|c|c|}
\hline Source & Frequency & $\begin{array}{l}\text { Cumulative } \\
\text { Frequency }\end{array}$ & $\%$ & Cumulative $\%$ \\
\hline Self & 146 & 146 & 33.3 & 33.3 \\
\hline $\begin{array}{l}\text { Assisted } \\
\text { Husband }\end{array}$ & 46 & 192 & 10.5 & 43.8 \\
\hline Children/family & 79 & 271 & 18 & 61.8 \\
\hline Hired Labour & 162 & & & 98.8 \\
\hline Others & 5 & 438 & 1.2 & 100 \\
\hline
\end{tabular}

In terms of women's works on the farm, it was observed that women are involved in the less strenuous works, while the more strenuous works like weeding, making of heaps and tree felling are done through hired labourers, who are usually men from their villages or migrants farmers who specialize in farm labours. Some still involve in hoeing, but at a very small level. Table 6 show a detailed distribution of women farmers when it comes to work performed on the farm.

This is in support of Olawepo and Yahaya (2010) who observed that women tend to take part less in energy sapping farming activities such as bush clearing and land preparation. The findings is also in line with the observation made by FAO (1998) that women were mostly responsible for sowing, weeding, application of fertilizers and pesticides, harvesting, threshing and marketing in Nigeria. 
Table 6. Women farmers according to their farm operation

\begin{tabular}{llll}
\hline Farm Operation & Frequency & Percentages & Cumulative \% \\
\hline Clearing of land & 24 & 12 & 12 \\
Planting/transplanting & 68 & 34 & 46 \\
Fertilizer & 24 & 12 & 58 \\
Weeding & 20 & 10 & 68 \\
Harvesting/transporting & 31 & 15.5 & 83.5 \\
Storage & 14 & 7.0 & 90.5 \\
Watering & 19 & 9.5 & 100 \\
\hline
\end{tabular}

Source: Authors' Research

\section{Animal Husbandry among Women}

In general women farmers in Ekiti Local Government Area of Kwara State keep live stocks. Which indicate that "women involvement in agricultural activities cut across every aspect of agriculture. Table 7 shows that 193 $(96.5 \%)$ of the respondents in the study area keep animals while the remaining 3.5\% (7) respondents do not keep animals. This shows that women participate in animal husbandry which is a branch of agriculture. The reason for those who have refused to keep live stocks might be lack of interest.

Table 7. Livestock ownership

\begin{tabular}{llll}
\hline Types o f Animals & Frequency & Percentages & Cumulative \% \\
\hline Goats & 67 & 33.5 & 33.5 \\
Sheep & 29 & 14.5 & 48.0 \\
Poultry & 59 & 29.5 & 77.5 \\
Turkeys/Duck & 17 & 8.5 & 86 \\
Rabbit & 3 & 1.5 & 87.5 \\
Piggery & 15 & 7.5 & 95 \\
Pigeon & 10 & 5.0 & 100 \\
\hline
\end{tabular}

Source: Researcher Field Work, 2007

Nevertheless, Table 7 reveals the percentage of various animals kept by women in the study area and they are arranged in order of magnitude, and based on this goat is first with $31.7 \%$ (181) of the respondent, followed by chicken which constitute $23.4 \%(145)$ of them, sheep $14.9 \%(85)$, pig $11.6 \%(66)$, duck $8.9 \%$ (51), pigeon 5.4\% (31) and Rabbit $1.2 \%(1)$. The least animal is rabbit, kept by only one respondent in Osi Opin, this may be as a result of high cost of maintenance and insufficient knowledge of the animal by the respondent.

Furthermore, pig is not found in all the communities i.e. Osi Opin and the reason discovered during interview is the religion barrier. Also, duck is not found in a place like Oke Opin and this is due to their belief about it. Observation shows that almost every woman involved in agriculture in this villages rears one animal or the other. Other domestic animal reared apart from the ones listed includes dogs and cat.

This result, gathered from the respondent is correlated to the information on the website (Gender and agriculture 2004) which says "in the livestock sector, women feed and milk the larger animals while raising poultry and small animals such as sheep, goats, rabbits and guinea pigs.

\subsection{Fishing Development}

Related to animal production and in line with the nutritional contribution of women farmers is in the area of fish production. Among the people of the area, it is noted that fishing is men's occupation, however, a substantial of women farmers in Ekiti are involved in fishery through the establishment of fish ponds either in their backyards or in the farm environment. Fishing production is one of the ways by which women are involved in nutritional development apart from their mothering roles. About 6.5\% (13) of our respondents are having local fish ponds either in their backyard of in near by locations. During the survey it has been discovered that fishing is not part of the major occupation among the people of Ekiti Local Government Area in Kwara State. Most of the output from 
such ponds are sold either in the local markets or sold to the retailers who later sell same to local resort centres. This was majorly noticed in Osi, Isolo-Opin and Araromi-Opin respectively.

Nevertheless, considering the operations performed on fish related functions, Table 8 shows that while $15.5 \%$ (31) of the respondents participate in drying the fish, $7.5 \%$ (15) do take part in smoking the fish.

Table 8 . Women according to the operation perform on fish

\begin{tabular}{lll}
\hline Fish Operation & Frequency & Percentage \\
\hline Ownership of Ponds & 13 & 6.5 \\
Fish Drying & 31 & 31 \\
Fish Smoking & 15 & 7.5 \\
Non fishing functions & 151 & 75.5 \\
\hline
\end{tabular}

Source: Authors' Research

\section{Cash flow and Farm Income}

In order to assess the level of incomes among rural women, sales from previous agricultural year were collated. Table 8 shows the average income of the women farmers based on the sale from the previous agricultural year. Income generally is low among women as a result of low capital input into production, low level of education, low price level of farm produce, and poor accessibility to credit facilities among others.

This aspect of the survey investigated the cash income of the women farmer in the study area. Table 9 indicates statistics on income level of the respondents. 2.5\% (5) of the respondents obtained N5000.00 in a month from farming while $30 \%(60)$ of the respondent realized between N5000 - N10,000.00 in a month and about $135(67 \%)$ of the respondent realized within the range of $\mathrm{N} 10,000$ to $\mathrm{N} 15,000$ respectively.

Meanwhile, those who experienced not more than N10, 000.00 in a month from the farm output attributed it to either inadequate investment, poor farming yields or other reasons they would not really explained. While those who realized between N10,000 to N15,000 accrued it from operating on big or very big farmland by employing hire labours on their farmlands, and later taking the farm output to another town or state to market. The farm out put such as cassava are processed to gari or cassava floor or yam to yam floor

and marketed. Almost all the women farmers take part of their farm produce for consumption.

Table 9. Average incomes of women farmer in the districts

\begin{tabular}{lllll}
\hline Income & Frequency & $\begin{array}{l}\text { Cumulative } \\
\text { Frequency }\end{array}$ & Percentage & Cumulative \% \\
\hline$>$ N5000 & 5 & 5 & 2.5 & 2.5 \\
N5000-N10000 & 60 & 65 & 30 & 32.5 \\
N10000-N15000 & 135 & 200 & 67.5 & 100 \\
\hline
\end{tabular}

Source: Authors Survey, 2007

This is generally low when compared to the National income of $\$ 1$ dollar per head per day as estimated by the United Nations. The low annual income accruing to the women farmers as revealed by the study shows that majority of them are still operating at subsistence level and then, the poverty cycle plays a dominant role.

When asked to speak further on the need for credit facilities in farm production, a lot of them are aware of its importance. Credit facilities or loan is a necessity in agriculture as it is needed to increase the capital base of farmers to bring about increased productivity. Most of their credit facilities are obtained through local and organized Cooperatives. The result of this study reveals that $52 \%(104)$ of the respondents belong to one co-operative society or the other while the remaining $48 \%(96)$ do not join any co-operative society. Epe has the highest number of those that operate co-operative among the women farmers followed by Osi, Oke-Opin, Etan and Obbo-Ile respectively. The small number of the people that operate co-operative can be accrued to illiteracy and the poverty level of the respondent. Example of the co- operative is National Union of Teachers Co-operative N.U.T., Farmers Co-operative Society which involves male farmers only, daily co-operation to mention a few. 


\section{Factors Determining Participatory Development of Women in Food Production}

In Order to explain the probable factors determining women participation in food production, twelve variables were considered .A stepwise multiple regression analysis was carried out, the dependent variable is the women participatory by districts (y) while factor $\mathrm{x} 1$ to $\mathrm{x} 12$ are the independent variables.

In all the 11 cases, three of the variables were found to be significant at the specified tolerance level of 0.05 for entry into the model. These are variable $\mathrm{x}$, [income supplement], $\mathrm{x} 2$ [debt servicing measure] $\mathrm{x} 4$ [food security].The multiple regression in table 4.28 suggests several findings.

Table 10. Multiple regression of determinant of participatory development

\begin{tabular}{lllllll}
\hline Variables & $\begin{array}{l}\text { Parameter } \\
\text { estimate }\end{array}$ & $\begin{array}{l}\text { Standard } \\
\text { Error }\end{array}$ & $\mathrm{R}$ & $\mathrm{R}^{2}$ & $\begin{array}{l}\% \\
\text { contribution }\end{array}$ & of \\
\hline Intercept & 1.0487 & 2.0310 & - & - & - & - \\
X1 & 3.0054 & 1.2129 & 0.83 & 0.6889 & 68.89 & 3.204 \\
X2 & 0.92384 & 0.3360 & 0.86 & 0.7396 & 73.96 & 1.003 \\
X4 & 0.05092 & 1.4143 & 0.87 & 0.7569 & 75.69 & 0.224 \\
\hline
\end{tabular}

Source: Authors computer out put, 2007

The variable $\mathrm{x} 1$ in each of the districts is probably the best predictor of women involvement in participation in food production. The correlation co-efficient of this variable of 0.83 and a coefficient determination $\left(\mathrm{R}^{2}\right)$ of 0.6889 . This indicates that about $68.89 \%$ differences in the participatory level of women in agriculture is explained by the variable $\mathrm{x} 1$; thus a high proportion of women are participating in farming and food production in order to supplement income. This noticeable especially in Etan, Obbo-ile, Obbo-Aiyegunle, Osi and Epe. This could be explained in term of the income accruing from foodlfarming venture. As the mainstay of the rural economy, the attraction to farming devices from the income that women derive from agricultural productions. In as much as incomes from other sources are low, farming is the next lucrative work that women can venture into. Money from this source will definitely assist them to acquire assets and meet household expenses.

Debt servicing measure(x2) also appeared to be very important determinant with a joint correlation 0.86 and co-efficient of determination of 0.7396 . This indicates that about $73.96 \%$ differences in the participatory level of women in agriculture and food production is explained by $\mathrm{x} 2$. This further means a large number of women are ivolved as a debt servicing measure and in family maintenance. This variable $\mathrm{x} 2$ however added about $5.07 \%$ in the level of explanation. This common to women around places like Isolo-Opin, Ishare-Opin, Obbo-ile, and Araromin-Opin. This also suggests that $73.96 \%$ of the joint variance in participatory level is collectively explained by the two variables $x 1$ and $x 2$. One can infer that the involvement of these women in food production could have a positive effect on debt servicing and as a regular income venture. This also relates to the poverty of the generality of women in the study area. Income from farming thus assist in servicing debts on other investment or family debenture activities in the rural environment.

The issue of food security (x4) also relate well to the variation in participatory level of women in food productivity with a joint correlation of 0.87 and a co-efficient of determination $\left(\mathrm{R}^{2}\right)$ of 7569 . This indicates that about $75.69 \%$ in the variation level is jointly explained by the three variables $\mathrm{x} 1, \mathrm{x} 2$, and $\mathrm{x} 4$. Variable $\mathrm{x} 4$ (Food Security) however added a mere $1.73 \%$ differences in explanation. This variable is an important determinant because a lot of women are into farming to boost food availability and the impact of rural women farmers is highly felt because their involvement encourages food availability.

In all, it could be deduced that three variables (income supplement, debt servicing measure and food security accounted for about $75.69 \%$ of the variance in the determinant of involvement of women in agriculture and food production in the study area, while the remaining seven variables do not have significant values in explaining the differences in participatory level. The explanatory regression equation could thus be written as:

$$
\begin{gathered}
\mathrm{Y}=1.0487+3.0054 \times 1+0.92384 \times 2+0.05902 \times 4 \\
\mathrm{RES}=75.69 \% \mathrm{E}=2.0310
\end{gathered}
$$

This means that an increase measure that would increase the number of women in agriculture would have appositive influence in their income generation level. In the same vein there would be a correspondence alleviation in debt servicing issue and more people would likely have access to food and thus ensuring a sort of food security in the rural area. 


\section{Conclusion}

From the research it is clear that women participate actively in agricultural production but lack the exposure and adequate to meet up mechanized farming. Women's role in production seriously is affected. This research reveals that apart from their mothering roles, Ekiti women have really contributed in to local food production. Apart from this, women agriculture has contributed to nutritional development, income generation, local employment through hired labour and general food security in the local environment.

Similarly, contrary to general opinion, the study has shown that women majorly participate in post farming operations such as harvesting, storage, watering, transporting. This is due to the tedious nature of farming preparations and cultivation. The research has also shown that women participate actively in animal husbandry and fishing. This is a form of nutritional development coming from the women fold.

The factors of supplementing income as a result of poverty, debt servicing and food security rank high in the motives that determine women participatory roles in food production and agriculture in the study area. In all, it could be deduced that these three variables (supplementing income/poverty level, debt servicing measure and food security) accounted for about $75.69 \%$ of the variance in the determinants of involvement of women in participatory food production, while the remaining variables do not have much significant in explaining the differences in the participatory level. This means that apart from production for subsistence, the income accruing from women farming drive women to wanting to be involved in agricultural production. Coupled with this is the poverty level among rural women generally.

In order to improve women participation in agriculture and food productivity in the rural areas, the following recommendations are essential for consideration. Rural women cooperative Societies could be encouraged among these rural women farmers. This will give them improved access to credit facilities, extension services and modern farming systems. This will also expose them to improved ways of land management system that will enlarge their horizon and consequently improved rural nutritional development and food security.

\section{References}

Adeyokunnu, T. O. (1981). Women Agriculture in Nigeria: A Research Series Publication. The African Training and Research Centre for Women, Ibadan

Amali, E. (1989). The Role of Women in Agric. Development Process. Development Studies Review, 3(1-2), 52-60.

Banwo, O. (1986). Food Prices and Inflation in the Tropics. Tropical Farming and Food Processing Magazine for Tropical Countries, 3(3), 11-15.

Egunjobi O. A. (1995). Women Involvement in Rural Agriculture and Agro Based Industries. Unpublished Seminar Paper on Women in Society.

F.A.O. (1995). Women in Developing Agriculture. UUN - ROME.

Lamming, G. N. (1983). Women in Cooperatives and Limitations to Full Participation. A Publication of the Human Resources Institute and Agrarian Reform Division, FAO Rome.

Meek, C. K. (1994). Land Law and Custom in the Colonies. Geoffrey Cumberlege, Oxford University Press.

Olawepo, R. A. (2012). Food Security and Challenges of Urban Agriculture in the Third World Countries, In Aladjadjiyan, A. (Ed.), Food Production; Approaches, Challenges and Tasks (pp. 55-66). Intech Publishers, Rijeka, Croatia. http://dx.doi.org/10.5772/34569

Olawepo, R. A., \& Yahaya, Y. (2010). Rural Women Performances and Participation in Agriculture: An Example from a Rural Nigerian Economy, Kogjourn, Department of Sociology, Kogi State University, Anyigba, Nigeria.

Olawoye, J. E. (1989). Difficulties of Rural Women in Securing Resources for Agric. Production: Two Case Studies from Oyo State, Nigeria. Journal of the Federal Dept. of Agric and Rural Development, 3(2), 78-85.

Olufade Ojo. (1997). Contribution of Women to Agriculture and their Extension Services. Journal of the Federal Dept. of Agric and Rural Development, 3(2), 38-45.

Oyedipe F. P. A. (1986). The Involvement of women in Rural Cooperatives in Nigerian Population. Education, FAO, Rome.

Pala, A. O. (1980). The Joluo Equation: Land Reform - Lower Status for Women. IIED Publications, Rome.

Tunde, A. M. (2011). Women Farmers and Poverty Alleviation in Small Towns of Kwara State, Nigeria. Unpublished Ph.D Thesis, Department of Geography and Environmental Management, University of Ilorin, Nigeria. 